\title{
BEMP Regimen
}

National Cancer Institute

\section{Source}

National Cancer Institute. BEMP Regimen. NCI Thesaurus. Code C10149.

A chemotherapy regimen consisting of bleomycin, vindesine, mitomycin and cisplatin that may be used in the treatment of disseminated squamous-cell carcinoma of the cervix. 